\title{
The Quest For Women Political Empowerment In Nigeria: The Role Of Mass Media
}

\author{
Dr. Mrs. A. T Ajayi \\ Department of History and International Studies, \\ Ekiti State University, Ado Ekiti
}

\begin{abstract}
This work derived its strength from secondary and primary sources. Women empowerment in Nigeria is a much debating theme and a harbinger of hard task as one have to recognize the reality of gender isolated issues and discrimination against women as social perniciousness since several years back. Empowering women aims to inspire women with the courage to break free from the chains of limiting self belief patterns and societal or religious conditioning that have traditionally kept women suppressed and unable to see their true beauty and power. Mass media plays one of the huge parts in women's improvement and its empowerment. Media can make an enlivening motivation to accomplish their potential as prime movers of progress in the public eye. Mass media will be engaged as one of the boss imperative elective necessities in helping the women empowered. It will help as the best means and access to stand in opposition to the mistreatment and underestimation of women at the grass root level. Along these lines, this examination will uniquely feature the positive viewpoints of mass media as a formative apparatus to depict and reverberates the perspectives and thoughts of women in Nigeria. The paper however derives its strength from both primary and secondary sources.
\end{abstract}

\section{INTRODUCTION}

Nigeria has an affluent history that is linked with the contributions of women who had impacted the politics of the nation towards a set goal of development; this has little or nothing to do with the fact that Nigeria is a patriarchal society. These various efforts have propelled scholars to push for more empowering efforts from politics for the female gender. Hence, tapping into the power of mass media to push for the said course is the focus of this paper. The various segments of the paper includes the historical overview of women empowerment in Nigeria; conceptual clarification; women empowerment in modern dimension; media role in empowering women in Nigeria and finally its conclusion. The data used are from both primary and secondary source.

\section{Historical Overview of Women Empowerment}

Empowering women has turned into a necessity in recent times, and as one of the objective of societal development (Mosedale, 2005). In the 1970s when women empowerment was first summoned by the Third World women's activist and women associations, it was logically used to outline and encourage the battle for social equity and women equity through a change of financial, social and political structures at national and worldwide levels (Bisnath and Elson, 2003). The need to engage women appears to fixate on the way that women have possibilities to add to the improvement procedure yet is obliged by a few factors that render them frail. While the purposes behind a specific women's frailty (or effectiveness) are numerous and fluctuated, it might be important to consider what women have in like manner in this regard. The basic factor is that, they are altogether compelled by their regenerative duties, societal standards, convictions, traditions and qualities by which social orders separate amongst them 
and men (Kabeer, 2000). These imperatives are molded by men commanded social structure (man centric society), high rate of destitution among women, and sexual orientation division of work.

In any case, concentrating on the empowerment of women as a gathering requires an investigation of gender relations, that is, the manner by which control relations between the genders are built and kept up. In man centric social orders like Nigeria, men have extreme specialist over material assets in the family unit, for example, land and cash crops, and over the work of women and other family individuals. Women having no immediate access to land and money yields or men's work, must request these assets from their spouses or from different men in the family unit to whom they are committed (Adams and Castle, 1994). Women's level of instruction, neediness and men's mentality towards women have throughout the years represented a genuine risk to women's investment being developed. Clearly level of training and financial states of women regularly decide their level of support in basic leadership both at family, group, state and national levels. There is for the most part unequal weight of local support and childcare obligations assigned to women when contrasted with men.

Women battles for political empowerment, support and acknowledgment dated back to the nineteenth century when women like Amina of Zaria, Madam Tinubu of Lagos, Olufumilayo Kuti of Abeokuta, Margaret Ekpo and Hajji Gabon Swabia among others battled to give Nigerian women the pride of place in the nation. Indeed, even after the battle for freedom was finished and Nigeria turned into an autonomous sovereign country, women kept on contributing their standard in the post-autonomy coordinate towards improvement and advance. In the territory of politics, the above named among others contributed gigantically to the preparation and refinement of women with a view to guaranteeing that women are associated with the politics of the nation.

In view, the issues relating to women have kept on drawing a worldwide consideration with the outcome that the issues that obstruct their advance are at present being tended to solidly by various associations and governments through the different accessible channels, eminently; mass media. Subsequently, the need for women political empowerment has increased the political awareness of women. Some of them involve key positions in government where they have kept on demonstrating their courage. For example Late (Mrs.) Dora Akunyili, Oby Ezekwesili, Ndi Okereke Onyilike and Ngozi Okonji Iweala among others have without a doubt separated themselves in their official assignments.

The part of women being developed has for long been underestimated and consigned to the back ground. For quite a while, politics in Nigeria has been played with the typical belittling disposition which for the most part does not go far in edifying women. A portion of the elements utilized are social and social practices which have been misjudged to make predispositions against women. There is requirement for women to be appropriately situated with the goal that their numerical quality and voting force can be beneficially electrifies and arranged towards empowerment of other women who will thus take care of the welfare of all women by defining sexual orientation touchy laws to advance women's motivation.

Contemporary encounters have demonstrated that mass media is imperative to the political improvement of countries. Mass media isn't just a method for educating, sharpening and transmitting messages on issues of advancement, yet in addition critical to the procedure of improvement. Considering the way that it is progressively being utilized worldwide with its energy of achieving an expansive mass of crowd, it ought not to be disregarded in the political 
plan of things. This may represent why Nwankwo (1996: 6) said that, 'one crucial factor in the quest for sexual orientation fairness in politics is the media'.

It isn't a shrouded actuality that women are underrepresented in the field of politics. This might be a result of the fundamental presumption that "a lady's place is in the kitchen". At the end of the day, her home obligations and family duties ought to be her sole need, subsequently undermining her dynamic interest in national improvement all in all.

The issue of sexual orientation inclination as well, contributes hugely to the low cooperation of women in politics. Beverly' (1995), takes note of that the general public expect that women ought to be moms, teachers, beauticians, secretaries, medical attendant, servants and social labourers just, along these lines, they needn't bother with training talkless of partaking in basic leadership. This notion isn't right, as the both men and women require and can tote politics and activities being developed, each in their own particular unique courses, nearby each other. The home too isn't forgotten in adding to female absence of interest in politics. In the home, spouses states of mind can specifically or in a roundabout way impact the decisions their wives make in whether to go into politics or not.

Numerous political gatherings, mirroring the more broad conditions in whatever is left of society, don't effectively acknowledge or advance numerous women into their echelons, not to mention allow women's control of vital positions inside these groups. This issue is especially vital in perspective of Abdullah's (1993) contention that to accomplish women freedom, it will be attached with equal developments.

\section{CONCEPTUAL CLARIFICATION}

A few terms are defined for clearness in the context within which they are utilized as a part of the work. Some of these terms are:

\section{Women Empowerment}

This is a procedure through which women procure abilities and readiness to fundamentally dissect their circumstance and make suitable move to change their status in the general public. It is a procedure of empowering women accomplishes control over their lives through extended decision. It incorporates women's entrance to instruction, landed property, political positions and contribution in financial- settling on exercises and basic leadership forms. It is an element of individual activity which is encouraged by institutional change and support.

Women empowerment has pulled-in the consideration of numerous researchers. Okpoko (2002:4) expressed,

"Women empowerment came into ubiquity with the women's activist development whose request was that women wind up enabled to take control of their own lives; to set their own particular motivation of what to do and how to do things that influence them".

The impact of women empowerment makes a capable effect on family, group standards, values and lastly the law that administers the group (Page and Czuba, 1999). As indicated by Stromquist (1995), women empowerment is a socio-political idea that includes subjective, mental, financial and political measurements. The intellectual part includes women's comprehension of the reasons for their subordination, minimization and valuing the need to settle on decisions that may conflict with social desires. The mental segment alludes to women's conviction and certainty that they can enhance their condition through individual and aggregate exertion. The monetary segment alludes to access to pay outside home through work that gives financial freedom. 
The political part includes the capacity to comprehend one's circumstance and prepare for change. Batliwala (1993:10) opined that "Empowerment isn't simply a difference in outlook ... however an obvious exhibition of that change which the world is compelled to recognize; react to and oblige admirably well". Batliwala additionally expressed that empowerment should begin from inside to include finding out from numerous points of view and figuring out how to tackle ones sound and passionate assets to accomplish wanted closures. Empowering women is considered as mindfulness building, especially about gender orientation imbalances in their social orders, building limits and creating abilities important to guarantee that women viably partake in present and future basic leadership and after that arranging women into groups which make a move to realize alluring changes, concentrating on more noteworthy correspondence amongst men and women in all choices (Batliwala, 1993).

Hashemi, Schuler, and Riley (1996) layout eight parts of empowerment, which incorporate portability, financial security, capacity to make little sales, capacity to make bigger sales, association in real choices, opportunity from mastery by the family, political and legitimate mindfulness and contribution in political battling and challenge. In any case, there are four fundamental viewpoints, which appear to be more relevant and acknowledged in women empowerment writing. Right off the bat, so as to be engaged an individual more likely than not been impaired; this implies women have been undermined particularly when contrasted with men. Furthermore, empowerment can't be given by an outsider; albeit a few organizations and government have made expansive endeavours in empowering women, clearly all the best they can do is to encourage women empowering themselves. Thirdly, empowerment means more than just a feeling of individuals settling on choices on issues, which are imperative in their lives. Fourthly, empowerment is a progressing procedure that individuals are enabled with respect to others or to themselves at a specific time (Mosedale, 2005).

Karl (1995) expressed that there are four phases of the empowerment procedure with respect to women and these incorporate mindfulness; limit building and aptitude improvement; cooperation and more noteworthy control in basic leadership; and activity for change. Garba (1999) included two more stages which incorporate limit and ability appraisal, and assessment organize, so as to encourage a more deliberate investigation of the empowerment procedure that is more appropriate to the empowerment of Nigerian women. As indicated by Garba (1999) the limit and abilities appraisals organize expands the shot that the required limit and aptitudes will be created. It is likewise seen to have methodological ramifications in that a need evaluation must be founded on the target states of a particular issue of disempowerment.

Batliwala (1994) laid out three ways to deal with empowerment which incorporate coordinated advancement, monetary empowerment, and cognizance rising. Incorporated improvement approach sees women's improvement as key progression of family and group. This approach continues by shaping of women's assemblages that take part being developed exercises and handle social issues, for example, disparity, endowment, youngster marriage, and male liquor abuse utilizing a particular action, for example, proficiency class or solid program to activate women into gatherings. The monetary empowerment approach credits women's subordination to absence of financial power. It centers on enhancing women's control over material assets. This is done through sorting out women for investment funds and credit, salary producing and expertise preparing exercises. The third approach is cognizance rising which states that women's empowerment requires consciousness of complex elements causing women's subordination. This is refined through training. 


\section{Gender and Politics}

Gender, a focal actuality of human character, is politically noteworthy in light of the fact that thoughts regarding sexual orientation have been utilized to legitimize different unequal medications amongst men and women. As indicated by Olurode (1990:12), 'Sexual orientation is a socially-forced division of genders'. Gender becomes politically vast when the conventional thoughts regarding sexual orientation and politics where asserted (Steans, 1998).

Sex issues have prompted two parallel patterns in the previous two decades: one is the issue of women and improvement and the other being the women's activist development and upsurge of women assembling and sorting out the world over to 'librates' themselves from social mistreatment and subordination. These battles have prompted new experiences into sexual orientation issues that make and sustain control and imbalance. Women's activists and improvement researchers/practioners are turning their searchlight on these issues and upholding for the mix of women into political advancement.

One subject normal to the arrangement of women empowerment fora from Mexico' 75, through Nairobi' 85, to Abuja' 89, Darker' 94 and Beijing' 95 is gender equal improvement. Today, gender issues have turned into a worldwide concern, particularly in the field of politics. Women's avoidance from politics came high on the plan at Nairobi world gathering to survey and evaluate the accomplishments of the UN Decade for Women in 1985 and the Beijing fourth World Conference on Women in 1995. All these have activated attention to rethink the social importance of women in broad daylight circle. (UNESCO, 1980)

\section{Women Empowerment in Nigeria}

Empowerment in my retribution is the non-appearance of the obstructions to the realization of regular longs for women. By this, empowerment would mean the leveling of the playing field with the end goal that men don't have an undue preferred standpoint in their quest to use the human potential whether in business, politics or other social stages. It is the opening of the space for women to have liberated access to instruction, aptitudes, and to partake in the basic leadership process on issues that influence them.

Concentrating on the empowerment of women as a group requires an investigation of gender relations, that is, the manner by which control relations between the genders are built and kept up. In male-centric social orders like Nigeria, men have extreme expert over material assets in the family unit, for example, land and money crops, and over the work of women and other family unit. Women having no immediate access to land and money yields or men's work, must request these assets from their spouses or from different people in the family unit to whom they are committed (Adams and Castle, 1994). Women's level of training, neediness and men's mentality towards women have throughout the years represented a genuine danger to women's investment being developed. Clearly level of instruction and financial states of women regularly decide their level of cooperation in basic leadership both at family, group, state and national levels. There is by and large unequal weight of household support and childcare obligations apportioned to women when contrasted with men. Male strength in sexual relations, with its result on women's absence of control over their sexuality in numerous social orders has denied women appropriate to decide the quantity of kids they need. They have a low basic leadership control as contrasted and men. The predominant male centric philosophy, which advances estimations of accommodation, forfeit, compliance and noiseless enduring frequently undermines the endeavors by women to advocate for themselves or interest for offer of assets and right (Hawkesworth, 1990). 
Empowerment in this manner requires an examination of women's subordination, the detailing of an elective more agreeable arrangement of game plans to those which exist. These can be accomplished through the lightening of the weight of household work and children mind, the expulsion of regulated types of separation, the foundation of political balance, enhancing the financial status of women, opportunity of decision over kid bearing, and taking measures against male brutality and control over women (Molyneaux, 1985). At the end of the day, empowerment requires change of structures of subordination through changes in law, property rights, and different foundations that fortify and propagate male control (Batliwala, 1994). This should be possible by enhancing the instructive, political and monetary status of women to empower them to partake effectively being developed procedures. It is this acknowledgment of the need women run their own particular lives, be a vital part of financial and political plan in their nations that the United Nations gave 10 years (1975-85) to issues concerning women and advancement. A definitive objective was to enable women to build up their possibilities, add to an advantage from improvement on rise to premise as men (United Nations, 1975).

In 1990s, numerous offices utilized the term women empowerment in relationship with a wide assortment of procedures including those which concentrated on expanding the decisions and profitability of women (Bisnath, 2001). Numerous meetings had been held with the goal to propel the status of women and take out gender-based segregation. Some of these gatherings incorporate Mexico Conference of 1975, Copenhagen Conference of 1980, Nairobi World Conference of 1985, and the 1995 Beijing World Conference. There had been different gatherings on women over the globe.

Numerous systems had additionally been set up to enable women, politically, monetarily and instructively in Nigeria. These procedures as per Okeke (1995) incorporate broadening women's entrance to instruction, empowering their full investment in real money economy, inspiring women to take part in politics and checking on laws on status of women.

The 1999 constitution gave advancement and assurance of women's privilege in Nigeria. The Federal government embraced the national arrangement on women in July, 2000. This arrangement gave, between alia, for governmental policy regarding minorities in society to increment to 35 percent women's portrayal in the administrative and official arms of government. The Federal Government has additionally set up the National Women Development Center as a parastatal to the Federal Ministry of Women Affairs. The Center is fundamentally responsible for look into ponders on women's issues (Women Aid Collective, 2008).

The Third Millennium Development Goal (MDG) concentrated on the advancement of gender fairness and empowerment of women. The United Nations Millennium Projects Task Force on instruction and gender equity has sketched out seven key needs to accomplish the Goal 3 of the Millennium Development Goals. These include: fortifying open doors for optional instruction of young ladies while meeting responsibility regarding general essential training; ensuring sexual and regenerative wellbeing and rights; putting resources into framework to lessen women's and young ladies time loads; ensuring women's and young ladies' property and legacy right; taking out gender imbalances in work by diminishing women's dependence on casual business, shutting gender holes in income and decreasing word related isolation; expanding women's offer of seats in national parliaments and neighborhood administrative bodies; and fighting brutality against young ladies and women (International Center for Peace Research on Women, 2005 Report). 
National governments, including Nigeria, have developed procedures and program to enable women politically, instructively and financially. Without a doubt, numerous states and towns that make up Nigeria have likewise profit by these activities and it has not prohibited Nsukka town. Some of these projects are composed by women themselves, government and nonlegislative bodies at group levels to help different projects at state, national and global levels. These activities incorporate, arrangement of women's associations that participate being developed situated exercises to handle social issues, for example, imbalance in political, financial and instruction segments, male strength, maternal and tyke wellbeing, youngster marriage, and other related issues. Different ways to deal with these activities incorporate monetary empowerment which centers on enhancing women's control over material asset. This could be accomplished by arranging women for investment funds and expanding women's entrance to credits, wage age, aptitudes preparing and other related exercises. These empowerment activities additionally include cognizance rising and collection of learning and thoughts, for it is recognized that women's empowerment requires consciousness of complex elements causing women's subordination. This is accomplished through training and other proficiency related exercises.

\section{Media's Role in Empowerment of women in Nigeria}

Correspondence is critical for women's improvement and mass media assume noteworthy part. It is to be noticed that development of women's instruction and their entrance into business has added to the development of media. In all circles of life whether for controlling populace development, spread of education or enhancing personal satisfaction for tremendous masses, women have critical part to play. In any case, women can be required to assume this part when they wind up aware of their quality and are not intentionally underestimated by male mastery. In this unique circumstance, media has an imperative part to play - to make arousing in women to accomplish their potential as the prime movers of progress in the public arena. In this day and age, print and electronic media assume an essential part in successfully passing on message that should be passed on.

All things considered the media scene in Nigeria is that media does not address significant issues about abuse and unequal treatment to women in various circles yet is sharp in announcing sex related occurrences by method for sensationalizing news of outrages on women. Subsequently as opposed to featuring the misuse of lady they wind up getting to be one reason in increment of brutality as their scope as a rule has a tendency to extol the wrongdoing against women. Beyond any doubt media has uncovered, as at no other time, certain misdeeds against women however in an extremely unobtrusive way it additionally sustained the stereotyped picture of lady as a householder and a unimportant substance in the conventional esteem framework. For the most part, women's issues never figure on the first page of a daily paper unless it is a grim murder or an instance of assault. Daily papers even on women's page does not generally address important issues for women empowerment but rather detailing is worried about magnificence tips formulas, design disorder and so forth.

Tragically that there is absence of affectability among the daily papers all in all to women and their issues. I might want to allude to the Study led by the Media Advocacy Group viz. "Viciousness against Women: Media Coverage and Representation". The Media Advocacy Group made the accompanying proposals on detailing brutality against the women.

(i) Media needs to take a broadened, more extensive perspective of violations against women. It must be instrumental in directing a social review on factors in charge of expanding wrongdoings, especially against women and kids, including detached investigative techniques, unnatural birth cycle of equity, and developing social exemption of the culprits of wrongdoing. 
(ii) It additionally must be instrumental in making mindfulness among common society of the causes and nature of the wrongdoing itself, and of the preventive measures.

(iii) When treating these issues, media must be to a great degree authentic and exact.

The examination likewise expressed that the main direction that administers a touchy covering this issue is that the assault casualty's name ought not to be unveiled.

The media, both electronic and print are ethically and lawfully bound to keep away from politicizing of news identifying with casualties of violations. The Press Council had officially drawn rules regarding the matter and claims to media to tail them fastidiously while revealing outrages on women/youngster. It is vital to allude now of time to, likewise an imperative issue that significantly and gravely impacts women in plain and in addition undercover way, the HIV/AIDS reportage by the media. The Press Council had concentrated on the issue route in 1993 when the AIDS was dealt with as a serious 'plague' and any individual who reached it was outcast. The prime sufferers of such shunning were the women, being dealt with as a critical reason and transporter of the purported disease.

Much dilute has flown the ganges, from that point forward and with therapeutic advances, it has turned out to be important for the media to center around the issue with not only a proactive but rather positive approach. Subsequently, the Press Council has in conference with the UNDP and the activists of the field redrawn the rules for media reportage that discover put in the trinket that will be in the blink of an eye discharged. I trust that rules, as simple to allude 'Dos' and Don'ts' and nitty gritty ones for indepth comprehension of the issue, will discover put on the work area of each medium individual and their scope of the HIV/AIDS stories will help the world handle the issue with more noteworthy affectability.

\section{CONCLUSION}

Women can be depicted as a key group in the advancement of any country. Women's empowerment makes a capable effect on group, family and the country as a whole. Subsequently, women empowerment can be viewed as an indispensable methodology for any improvement exertion. Albeit a few activities have been built up by government, nongovernmental bodies and individual, a few components have constituted requirements to women's contribution in these activities. Obliviousness of the presence of these activities, absence of enthusiasm among women and confinement from spouses and different men has denied women access to these activities. This research uncovered that wage level and instructive level have noteworthy associations with women's support being developed procedures. This further backed the perspective of Lasiele (1999) that inclination to youths instruction needs to low instructive empowerment of women which has prompted their poor investment being developed process. He additionally declares that poor monetary bases of women have likewise influenced women's interest being developed procedures. Along these lines, to help enhance the cooperation of Nigerian women formative procedures, they ought to be engaged politically, instructive and monetarily.

The investigation likewise uncovers that mass media has fundamentally helped women's cooperation in formative process. It was watched that numerous elements still constitute boundaries to dynamic cooperation of women being developed procedures. There is requirement for government, non administrative bodies and people to work as one in taking out or lessening these limitations with a specific end goal to make favorable condition for women to effectively take an interest in the advancement procedure and for reasonable media outlets where dialogs will be objective and not subjective. This will prompt maintainable improvement in Nigeria. 


\section{References}

Abdullah, H. (1993). Transition Politics and the Challenge in Nigeria, Review of African Political Economy, No

Abiola AA (Ms), Lanre A (eds.) (2003). Gender Audit - 2003 Election and Issues In Women's Political Participation In Nigeria, A Publication of Women Advocates Research And Documentation Centre (WARDC).

Afshar, H (1996) Women and Politics in the Third World. London: Rutledge.

Agoawike, A 2000). Images of Women in the Media, in day Champion Newspaper of December 31, 2000.

Anifowose R (2004). Women Political Participation in Nigeria: Problems and Prospects in Akinboye SO (ed.)

(2004). Paradox of Gender Equality in Nigerian Politics Concept Publication Limited Lagos.

Annenberg, W (1988) The fourth Branch of Government". In Herbert, R and Reuses, (Eds) impact of Media. New York: Longman.

Azikiwe, U. (1992). Women education and empowerment. Nsukka: Fulladu Publication Company.

Batliwala, S. (1994). The meaning of women's empowerment: New concepts from action. In G. Sen, A. Germain \& L. C. Chen (Eds.), Population policies reconsidered: Health, empowerment, and rights (pp.128-138). Boston,

Massachusetts: Harvard University Press

Beverly, A. (1995). Building Gender Fairness in Schools. U.S.A Southern Illinois University Press.

Charlton, S.E. (1989) Women the state and Development in Everett, and Stuart, K (Eds). New York: State University Press.

Cook, R.J (1993) Woman's International Human Rights Law: the way forward. Human right Quarterly 15: The John Hopkins University Press.

Gallagher, M (1990) Woman and Men in Broadcasting: Prospects for Equality in the '90s' Brussels: Commission of European Community

Irukwu, E (1994) Footprints: The Evolution of Nigerian Women.Lagos: Talkback Publishers Ltd.

Kira S (2003). Gender-Related Knowledge and the Descriptive Representation of Women, Pol. Behav. 25(4).

Kontagora, (2005) Stimulating Female Participation in Technological Education. In Kaduna Polytechnic. Journal of Women in Technical Education, vol, 40.

MacBride, S, et al (1981) Many Voices One World._ Ibadan: University Press.

Nkoyo N (2002). "Women are looking for new partners for empowerment" in community magazine CAPP Publication 5(1). Phillips A (1995). The Politics of Presence. Oxford: Polity Press.

Nnoli, O. (1986). Introduction to Politics_. Ibadan: Longman Publishers Ltd.

Nwankwo, N. (1996). Gender Equality in Nigeria Politics. Lagos: Deutchetz.

Obasi, F. (2008). A Handbook on Research Proposal Writing. Enugu: Ruwil Nudas Graphics.

Okagbue, l (1996) Women's Rights are Human Rights._Lagos: Nigerian Institute of Advanced Legal Studies Press.

Olojede, l (1990) “Woman, power and Political System", in Olurode, L (Ed) Woman, Social Change and Perception of Gender Roles. Lagos: Unity Publishing and Research Co.

Olurode, L (1990) “Woman, Social Change and Perception of Gender Roles", in Olurade, L (ed) Women and Social Change in Nigeria. Lagos: Unity Publishing and Research Co.

Rosaldo MZ, Louise L Eds. (1974). Women, Culture and Society, Stanford University Press.

Sob wale, 1 (1985) Influence of Ownership on Nigerian Newspaper coverage on National Issues in Nwuneli, in: O.E (Ed) Mass Communication in Nigeria: A book of Readings. Enugu: Fourth Dimension publishers.

Steans, J (1998) "States, Nationalisms and Gender Identities", in Steans, J (Ed) Gender and International Relations: An Introduction. Cambridge: Polity Press.

The 1999 Constitution of the Federal Republic of Nigeria. UNESCO (1999). Unit for the Promotion of the Status of Women and Gender Equality, Passport to Equality, Paris.

UNDP (1995) Human Development Report.New York: UNDP.

UNDP (1995) the Platform for Action and the Beijing declaration New York: United Nations Development of public Information. 
UNESCO (1980) Woman in the Media, Paris: UNESCO

Williams, B.A (2008) "Stakeholders Take Stock of Women Participation in Politics; in Sunday Guardian Newspaper of July 6, 2008.

Winter, A., \& Bellow, I. (1968). People in Politics. London: Oxford University Press. (10 ${ }^{\text {th }}$ ed). 